\title{
THE TWENTY-FIRST CENTURY - THE BEGINNING OF A NEW ERA IN THE PROTECTION OF HUMAN RIGHTS OF PERSONS WITH MENTAL HEALTH DISABILITIES
}

Summary: $\quad$ The paper analyses Art. 12 of the Convention on the Rights of Persons with Disabilities and its implications for the position of persons with mental disabilities. The new concept of legal capacity contained in Art. 12 should ensure that fundamental human rights of these persons are no longer "a dead letter on paper". However, once the Convention came into force, the implementation of this provision has proved to be problematic for States Parties. Diane Kingston, former Vice-Chairperson of the Committee on the Rights of Persons with Disabilities, best expressed the scale of the problem in October 2015 when she emphasized that no country had until that point fully met the requirements contained in Art. 12. Given that the Convention is a document that prescribes the fundamental human rights, the statement that no national legislation is consistent with its key provision is confusing and worrying. Therefore, a special attention should be paid to Art. 12 and its implementation in practice.

Keywords: $\quad$ CRPD, persons with mental disabilities, human rights, legal capacity, mental capacity, supported decision making

\section{INTRODUCTION}

Respect for human dignity, personal autonomy, independence, equality, and non-discrimination is the fundamental human right guaranteed without exception to everyone in a range of international documents. These are rights that are universal and generally accepted, and are not put into question. But, in spite of this, reality has shown that persons with mental disabilities cannot always achieve the full extent of those rights. Numerous researches, as well as the practice of the European Court of Human Rights have confirmed that there is still a great gap between the prescribed rights of persons with mental disabilities and their implementa-

Marissabell Škorić, PhD, Associate Professor, Faculty of Law, University of Rijeka, Hahlić 6, 51000 Rijeka, Republic of Croatia. Email address: skoric@pravri.hr. ORCID: https://orcid.org/0000-0003-0627-3651. 
tion in practice and that these persons have been, to a greater or lesser extent, marginalized, neglected, threatened, and abused in many countries. ${ }^{1}$ There are many causes of such a condition, but it has been shown that the source of the majority of problems, which persons with mental disabilities face, is their being restricted or denied the legal capacity. Without the legal capacity, a large array of rights, which they are guaranteed, remains "a dead letter on paper".

In most legal systems, legal capacity is acquired from the age of eighteen when an individual legally assume control over his or her actions. From that moment on he or she can independently make important decisions about their life, such as where or with whom to live or work. The demands for autonomy and independence are inherent to every man and the ability to realize them plays an important role in building self-confidence and self-esteem. These are also traits whose development is encouraged from early childhood, but it has been shown that different rules apply to persons with mental (or psychosocial) disabilities. Such persons have always been exposed to a large number of prejudices that determine the attitude of society towards them as persons unable to live independently and who, in turn, are dependent on someone else's provision of care. This practice had its basis also in legal norms. Namely, almost all national legislations prescribe that, under certain conditions, persons with mental health disabilities may be denied their legal capacity. ${ }^{2}$ By losing legal capacity, the person also loses a wide range of rights; their decisions no longer have legal significance and they become dependent on a guardian who takes full control of their life. ${ }^{3}$

Although the institute of guardianship has been introduced primarily to protect persons with restricted or denied legal capacity, there are many examples of breaching the law and unethical procedures that have compromised it. Instead of protecting the rights of these persons, guardianship has often been a cover for their exploitation. Namely, a series of researches, as well as practice of the European Court of Human Rights ${ }^{4}$ points to numerous abuses of the institute of guardianship and the violation of fundamental human rights of persons under guardianship. ${ }^{5}$

The creators of the Convention on the Rights of Persons with Disabilities ${ }^{6}$ have recognized that legal capacity lies at the heart of all individual freedoms, ${ }^{7}$ or as Quinn said: "Legal capacity

1 See M. S. v. Croatia n. 2, (2015), Bureš v. Chech Republic, (2012), Filip v. Romania, (2006), Winterwerp v. Netherlands, (1979) etc.

2 Persons with mental health disabilities can be fully or partially deprived of their legal capacity in all but two EU Member States. See Legal capacity of persons with intellectual disabilities and persons with mental health problems, European Union agency for fundamental rights, Luxembourg: Publications Office of the European Union, 2013, p. 31. URL=https://fra.europa.eu/sites/ default/files/legal-capacity-intellectual-disabilities-mental-health-problems.pdf. Accessed 8 May 2019.

3 Throughout history legal capacity was denied to many groups (including women) based on perceived characteristics of inferiority, but it seems that today persons with cognitive disabilities are the only group to which it can be denied. Flynn, E.; Arstein-Kerslake, A., The Support Model of Legal Capacity: Fact, Fiction, or Fantasy?, Berkeley Journal of International Law, Vol. 23, No. 1, 2014, pp. $124-125$.

4 Lashin v. Russia, (2013), Stanev v. Bulgaria (2012), X and Y v. Croatia, (2011), Shtukaturov v. Russia, (2008) etc.

5 "Guardianship has been overused and abused in the medical, as well as other, contexts, including at the most extreme level to place persons with intellectual disabilities in psychiatric institutions. This is inappropriate medically and socially and is inconsistent with the rights of persons with intellectual disabilities to health, autonomy, participation, non-discrimination and social inclusion". Report of the Special Rapporteur on the right of everyone to the enjoyment of the highest attainable standard of physical and mental health, Hunt, P., Report to the Sixty-first session of the Commission on Human Rights, 11 Feb. 2005, E/CN.4/2005/51, § 79.

6 Convention on the Rights of Persons with Disabilities was adopted on 13 December 2006 and entered into force on 3 May 2008 [hereinafter CRPD]. The CRPD was signed by 81 countries and the European Union on the very first day since it was available for signing. Initial enthusiasm continued, and so far, the Convention has been ratified by 179 countries.

7 A significant background factor in the emphasis on legal capacity in the CRPD is the widespread abuse of the rights of persons with disabilities, which leads to their "civil death", i.e., losing almost all civil rights. Szmukler, G., "Capacity", "best interests", "will and preferences" and the UN Convention on the Rights of Persons with Disabilities, World Psychiatry, Vol. 18, No. 1, 2019, pp. 34-35. 
to me is a continuum that connects with everything needed to enable the person to flousish [sic] - a right to make decisions and have them respected, a place of one's own, a life in the community connected to friends, acquaintances and social capital, whether in public or private settings. Personhood is broader than just capacity - and these broader connections serve to augment capacity in a virtuous circle". ${ }^{8}$

In Art. 12 the creators prescribed a new concept of legal capacity that should enable persons with mental disabilities to finally gain the opportunity to realize their potential and be recognized as equal members of society. ${ }^{9}$ Unlike all earlier human rights documents which, though envisaged also as a framework for the protection of persons with mental disabilities, in principle started off from the fact that these persons are incapable of exercising certain rights and therefore gave others broad discretion to enforce their will, in Art. 12 the CRPD insists on the respect for their autonomy and right to self-determination. ${ }^{10}$ This provision is not only a step forward with regards to the existing regulation on the issue, but is the most revolutionary among the new norms articulated in CRPD, ${ }^{11}$ which is considered the beating heart of the Convention. ${ }^{12}$ Therefore, it is not surprising that its implementation is marked as a special priority and that the harmonization of national legislation with the content of Art. 12 is regarded as crucial to the realization of all other rights guaranteed by the CRPD. ${ }^{13}$ Upon its entry into force in 2008, the CRPD created tremendous expectations but at the same time it also raised the first questions related to the interpretation of Art. $12 .{ }^{14}$ As Diane Kingston said in October 2015, the main problem regarding Art. 12 is its applicability in practice. ${ }^{15}$

The primary aim of this paper is to emphasize the enormous importance and series of positive aspects of Art. 12, for people with mental disabilities and their right to autonomy, but also to point the potentially negative implications that can emerge as a result from the

8 Quinn, G., Rethinking Personhood: New Directions in Legal Capacity Law \& Policy or How to Put the "Shift" back into "Paradigm Shift", in: Janjic, B.; Beker, K.; Marković, M. (eds.), Legal capacity and community living: protection of the rights of persons with disabilities, Mental Disability Rights Initiative MDRI-S, Belgrade, 2014, pp. 17-39, p. 18.

9 In order to better understand the significance of the CRPD for persons with mental disabilities and particularly its Art. 12, it is important to become familiar with the fundamental specificities of the historical development of the legal and real position of these persons. For more see Degener, T.; Begg, A., From Invisible Citizens to Agents of Change: A Short History of the Struggle for the Recognition of the Rights of Persons with Disabilities at the United Nations, in: Della Fina, V.; Cera, R.; Palmisano, G., (eds.), The United Nations Convention on the rights of persons with disabilities: A Commentary, Springer, 2017, pp. 1-39.

10 Several structural features have been added to the text of the CRPD, which should enable a wider implementation of the CRPD than other human rights documents. Lewis, O., The Expressive, Educational and Proactive Roles of Human Rights: An Analysis of the United Nations Convention on the Rights of Persons with Disabilities in: McSherry, B.; Weller, P. (eds.), Rethinking rights-based mental health laws, Hart Publishing Ltd, Oxford and Portland, Oregon, 2010, p. 113.

11 Minkowitz, T., The United Nations Convention on the Rights of Persons with Disabilities and the right to be free from non-consensual psychiatric interventions, Syracuse Journal of International Law and Commerce, Vol. 34, No. 2, 2007, p. 408.

12 Nilsson, A., Who gets to decide? Right to legal capacity for persons with intellectual and psychosocial disabilities, Council of Europe: Commissioner for Human Rights 2012, p. 14. URL= https://rm.coe.int/16806 da5c0. Accessed 8 May 2019.

13 Dhanda, A., Universal legal capacity as a universal human right, in: Dudley, M.; Silove, D.; Gale, F. (eds.), Mental health and human rights: vision, praxis, and courage, Oxford University Press, 2012, p. 181.

14 Art 12. is one of the most interesting, most controversial and most important provisions of the CRPD given its application to persons with mental disabilities. Korać Graovac, A.; Čulo, A., Konvencija o pravima osoba s invaliditetom - novi pristup shvaćanju prava osoba s duševnim smetnjama, Zbornik Pravnog fakulteta u Zagrebu, Zagreb, Vol. 61, No. 1, 2011, p. 73.

15 Izvješće o radu Pravobraniteljice za osobe s invaliditetom za 2015, pp. 19-20. URL=http://posi.hr/wp-content/uploads/2018/01/ IZVJESCE-O-RADU-UREDA-PRAVOBRANITELJICE-ZA-OSOBE-S-INVALIDI TETOM-ZA-2015.pdf. Accessed 8 May 2019. 
insistence on its radical interpretation. ${ }^{16}$ In the conclusion, it will be attempted to provide an answer to the question whether the CRPD creators could have done their job better, i.e., if they could have written more clearly one of the most important provisions of the CRPD, thus avoiding any controversies arising from its interpretation today. It is also possible that they have done their best given the current circumstances and by withholding explicit answers to some questions, they have made a big step forward in the direction of actually improving the position of persons with mental disabilities in society.

\section{ART. 12 - THE BEATING HEART OF THE CONVENTION ON THE RIGHTS OF PERSONS WITH DISABILITIES}

Already during the drafting of the CRPD text it was undeniable that the traditional approach to the interpretation of legal capacity of persons with disabilities had to change, ${ }^{17}$ but opinions varied with regards to the direction in which these changes should go. Thus, there are considerable disagreements around the definition of the term legal capacity and the question whether persons with disabilities should be restricted or denied legal capacity, or whether the model of substitute decision-making could still exist. ${ }^{18}$ Yet, after a long and heated debate, an agreement was reached and the text of Art. 12 was adopted. However, this did not bring an end to the controversies. Namely, in a still predominantly paternalistic society, the harmonization of national legislation with the provision of Art. 12 has proven to be (too) big of a challenge for States Parties. While analyzing their reports on the implementation of the CRPD, the Committee concluded that Member States have failed to understand the exact scope of the obligations arising under Art. 12 and have not made significant changes to their legislations. This, in turn, encouraged the Committee to create the General Comment no. 1, Art. 12: Equality before the Law in 2014, whose purpose was to clarify disputed issues related to the content of Art. 12 and to ensure its unique application in Member States. ${ }^{19}$ However, this did not happen; moreover, the controversy over the content of this provision continued and some of the Committee's conclusions have opened up new questions that are discussed in more detail in the continuation of this text.

16 Although "disabilities" is not formally defined in the CRPD, it is accepted by the Committee on the Rights of Persons with Disabilities [hereinafter the Committee] that people with mental disabilities (or "psychosocial disability") fall under the CRPD. The Committee is a body of independent experts monitoring the implementation of the CRPD in States Parties. For more on the Committee see Stein, M.; Lord, J., Monitoring the Convention on the Rights of Persons with Disabilities: Innovations, Lost Opportunities, and Future Potential, Human Rights Quarterly, Vol. 12, 2010, pp. 691-700.

17 Compare Bell, S.; McGregor, J.; Wilson, M., The Convention on the Rights of Disabled Persons: A Remaining Dilemma for New Zealand?, New Zealand Journal of Public and International Law, Vol. 13, No. 2, 2015, p. 295.

18 The CRPD does not provide an explicit answer to the question whether Art. 12 contains a rebuttable or an irrebuttable presumption of enjoyment of legal capacity. For this reason, some countries have been reserved in implementing this provision during the ratification of the CRPD. For example, Canada interprets Art. 12 in a way that includes rebuttable presumption of the existence of legal capacity. However, despite such an attitude, it is interesting to observe that Canada has made reservation, due to the belief that its legislations are not harmonized with Art. 12. Caivano, N., Conceptualizing Capacity: Interpreting Canada's Qualified Ratification of Article 12 of the UN Disability Rights Convention, Western Journal of Legal Studies, Vol. 4, No. 1, 2014, pp. 15-18.

19 United Nations Committee on the Rights of Persons with Disabilities, General Comment no 1: Article 12: Equal recognition before the law, CRPD/C/GC/1, adopted 11 April 2014 [hereinafter General Comment]. 


\subsection{MEANING OF THE TERM "LEGAL CAPACITY”}

There is no one generally accepted definition of legal capacity; therefore, States define its content differently. Some States define legal capacity as legal standing or capacity to hold rights and duties; others define it as the legal agency or capacity to exercise rights and duties; and some States in definition include both the capacity to have rights and capacity to exercise rights. ${ }^{20}$

Due to different definitions of the term legal capacity in UN Member States, discussions were held during the negotiations on whether the term legal capacity should include legal agency or if it should be limited solely to legal standing. ${ }^{21}$ One of the proposals was to adopt a compromise solution according to which an additional note should be inserted in the Art. 12(2). This note would prescribe that in three of the six official UN languages (Arabic, Chinese and Russian) the meaning of legal capacity would refer solely to the legal standing, thereby limiting legal capacity only to capacity to have rights. ${ }^{22}$ However, this proposal jeopardized the possibility of achieving the purposes of the CRPD itself and opened up a number of other legal questions. Namely, only the concept of legal capacity that includes both legal standing and legal agency makes the person a subject of the law and grants them autonomy and independence. ${ }^{23}$ This broader understanding of the term legal capacity is of paramount importance for persons with mental disabilities. Namely, their legal standing has never been disputed, but their legal agency, i.e. the capacity to make legally relevant decisions, is. Without it, as has been noted before, most other rights guaranteed to them cannot be realized. Therefore, enormous efforts of civil society associations to eradicate this note come as no surprise and neither do the efforts of certain States which have justifiably insisted on a single interpretation of the concept of legal capacity in all States Parties. ${ }^{24}$ In the end, their efforts have come to fruition and the note was deleted from the proposal of the final text of the CRPD.

Disputes arising from the content of this term continued even after the CRPD came into force, ${ }^{25}$ but most authors agree that the term legal capacity referred to in Art. 12 should be understood in its widest sense to include capacity for rights and capacity to act. ${ }^{26}$ This conclu-

20 Caivano, op. cit., note 18 , p. 9.

21 The question regarding the definition of legal capacity has been raised before. The Committee on the Elimination of Discrimination against Women made the following conclusion on this issue: "When countries limit a woman's legal capacity by their laws, or permit individuals or institutions to do the same, they are denying women their rights to be equal with men and restricting women's ability to provide for themselves and their dependents." See U.N. General Assembly, Report of the Committee the Elimination of Discrimination against Women, § 8, U.N. A/49/38 (Apr. 12, 1994).

22 For more see Schulze, M., Understanding the UN Convention on the Rights of Persons with Disabilities, A Handbook on the Human Rights of Persons with Disabilities, Handicap International, 2009, pp. 60-65.

23 Legal standing without legal agency means little. For example, legal standing allows a person to be the owner of a house, but if the person does not have legal agency, then he or she cannot conclude a contract that will enable him or her to exercise that right.

This attitude has been adopted by, among others, EU Member States. See Lintonen, Letter dated 5 December 2006 from the Permanent Representative of Finland to the United Nations addressed to the Chairman, U. N. General Assembly, A/ AC.265/2006/6 (Dec. 5, 2006).

25 The first official translation of the CRPD into Croatian understood only legal standing under the term legal capacity (The Official Gazette, International Treaties, 67/2007), but the subsequent correction included legal agency as well (The Official Gazette, International Treaties, 5/2008).

26 See Bartlett, P., The United Nations Convention on the Rights of Persons with Disabilities and Mental Health Law, Modern Law Review, Vol. 75, No. 5, 2012, p. 764, Callaghan, S.; Ryan, C., An evolving revolution: Evaluating Australia's compliance with the Convention on the Rights of Persons with Disabilities in Mental Health Law, UNSW Law Journal, Vol. 39, No. 2, 2016, p. 602, Minkovitz, op. cit., note 11, pp. 410-411, Caivano, op. cit., note 18, pp. 8-9. 
sion was confirmed by the Committee, which expressly observed in the General Comment that "legal capacity includes the capacity to be both a holder of rights and an actor under the law." 27

\subsection{CAN LEGAL CAPACITY BE RESTRICTED OR DENIED TO A PERSON WITH MENTAL DISABILITIES?}

Whether or not the possibility of restricting or denying legal capacity should be envisaged and some form of guardianship kept was the subject of lengthy discussions during the process of creating the CRPD. A part of the delegates considered that some form of guardianship should be ensured for those exceptional cases when a person cannot carry out their legal capacity and they advocated that this issue be regulated in the CRPD. This view is in line with the existing practice of most European countries which prescribe in their national legislation conditions and procedures for the restriction and denial of legal capacity. In this case, most of them accept the so-called functional model of denying legal capacity (functional approach), according to which an individual's absence of cognitive abilities, i.e. his or her inability to understand (comprehend) the nature and consequences of a certain decision (mental capacity) is the foundation for the restriction or denial of legal capacity. ${ }^{28}$ Consequently, the decision-making capacity was accepted as a legitimate basis for the legal capacity. Precisely the assessment of certain psychological functions of a person is the demarcation line between those decisions that have a legal effect and those that do not. Decisions and preferences of persons with mental capacity are respected, while legal capacity is denied and a guardian is appointed to those persons who do not have mental capacity. ${ }^{29}$

On the other hand, a significant number of delegates considered that the system of guardianship and substitute decision-making has throughout history resulted in a lot of injustice and has caused unforeseeable adverse consequences for persons with mental disabilities so that it is imperative to replace it with new solutions that will be based on respect for the rights, will and preferences of the person to which the decision applies.

Although some working drafts of Art. 12 foresaw the guardianship system as the last resort in cases where it is not possible to determine the true will of the person, ${ }^{30}$ the final text of the CRPD does not mention substitute consent. Unlike most national legislations, as well as a

27 General Comment, op. cit., note 19, §12.

28 There are three commonly known models of denying legal capacity. In addition to the functional model, there is the so-called status approach according to which the existence of a certain form and degree of disability suffices for the denial of legal capacity, regardless of the person's true capacity and, the so-called outcome approach, which is focused on the reasonableness of the decision the individual has made on his or her own.

29 Experts agree that the following four aspects should be taken into account when assessing mental capacity: understanding information important for decision-making, capacity to evaluate or apply information to one's own situation, capacity to use that information in the decision-making process and the capacity to communicate a clear decision or a consistent choice. McSherry, B., Decision-Making, Legal Capacity and Neuroscience: Implications for Mental Health Laws, Laws, Vol. 4, 2015, pp. 128129. See Štrkalj Ivezić, S., Procjena kapaciteta za odlučivanje kao ključan faktor u donošenju odluke za lišavanje poslovne sposobnosti, in: Poslovna sposobnost i skrbništvo - raskorak između Konvencije o pravima osoba s invaliditetom i prakse, Pravobraniteljica za osobe s invaliditetom, Zagreb, 2012, p. 67

30 See U.N. General Assembly, Report of the Ad Hoc Committee on a Comprehensive and Integral International Convention on the Protection and Promotion of the Rights and Dignity of Persons with Disabilities on its seventh session, Annex 2, Art. 12, A/AC.265/2006/2 (Feb. 13, 2006), Schulze, op. cit., note 22, pp. 60-65. 
number of other human rights documents that foresee that under exceptional circumstances a person with mental disabilities may be denied their legal capacity, the CRPD does not contain such a provision. ${ }^{31}$ From the adopted text of Art. 12 it is clear that it was the intention of the Convention's creators to replace the previous model that has allowed for the removal of legal capacity and the appointment of guardians with a new model based on the assumption that all persons enjoy legal capacity. The Convention's creators thereby did not deny that an individual may have a particular impairment that could, to a greater or lesser extent, affect their decision-making capacity. But at the same time, they made a clear departure from the current practice in which, in such cases, a person would be denied their legal capacity and appointed a guardian who would make decisions on their behalf. Instead, Art. 12 calls on States Parties to provide persons with disabilities with the support they need to exercise their legal capacity and it insists that, when providing such support, the rights, will, and preferences of the person to whom the support is provided are respected.

The Committee has also addressed this issue. In its view, the principle of equality requires the recognition of universal legal capacity of all persons, regardless of their disability or decision-making skills and the States are obliged to abolish the denial of legal capacity on the basis of disability because such practice is discriminatory. ${ }^{32}$ In the opinion of the Committee, legal capacity and mental capacity are two different concepts. Legal capacity comprises the ability to hold rights and duties and the ability to exercise those rights and duties and it is the key to participating in society. Mental capacity refers to the ability to make decisions and this differs from person to person and is the result of a complex interaction of different influences, including the environment and social factors. The basic starting point of the Committee is that legal capacity must be independent of the decision-making capacity, i.e., that "deficits in mental capacity must not be used as justification for denying legal capacity." ${ }^{33}$ It is this demand that marks a significant departure from the existing contemporary legislations that consider the existence of the decision-making capacity crucial to the recognition of legal agency, ${ }^{34}$ which in a number of States is synonymous with legal capacity. A direct consequence of this kind of interpretation is that every person has the right to independently make decisions, without the interference of others and their capacity to do so must not be questioned. In the opinion of the Committee, legal capacity must be separated from the concept of mental capacity, which is in and of itself extremely controversial, non-objective and not based on scientific criteria. Consequently, the Committee finds the functional approach to denying legal capacity, which is accepted in most States, to be unacceptable because it is discriminatory and founded on the wrong premise that we are able to accurately analyze the inner-workings of the human mind. In this respect, the Committee does not dispute the possibility that a person might be suffering from a certain type of impairment, but, in its view, this cannot be the basis for the abolition of legal capacity. The obligation is rather imposed on States Parties to provide the person

31 Previous documents adopted by the U.N. did not deal with the justification of denying legal capacity. Their attention was focused on the establishment of protective mechanisms that would prevent abuses, but they did not question the possibility that certain rights would be restricted or denied to persons with mental disabilities. See U.N. General Assembly, Principles for the Protection of Persons with Mental Illness and for the Improvement of Mental Health Care, G.A. Res. 46/119, (Dec. 17, 1991) and U.N. General Assembly, Declaration on the Rights of Mentally Retarded Persons, G.A. Res 2856 (XXVI), (Dec. 20, 1971). 
with the necessary support so that they could realize their legal capacity. It is also important to emphasize that the Committee considers that the support given to a person to realize his or her legal capacity should not depend on the assessment of mental capacity. In its opinion, it is necessary to determine some other grounds to do so that are not as discriminatory as mental capacity, but the Committee has not specified what such grounds might be. ${ }^{35}$

The Committee's views on this issue are complemented by the conclusion that States must replace substitute decision-making with supported decision-making. ${ }^{36}$ The Committee insists on the interpretation of Art. 12 in a manner that calls for a complete abolition of substitute decision-making and considers that the States which prescribe both systems, i.e. supported and substitute decision-making, do not meet the requirements of Art. 12 of the CRPD. The Committee does not deny that persons with mental disabilities occasionally need support in carrying out their legal capacity and in that sense the States are obliged to take the appropriate measures to ensure this support; however, this support must not grow into substitute decision-making. In other words, the Committee insists on abolishing the system of guardianship and setting up a system of support that will ensure that the will and preferences of the person are always and in every case respected. In this regard, the Committee broadly defined support by including formal and informal agreements on different degrees of intensity and type of support, such as trusted support persons, advocacy, peer support or assistance with communication. ${ }^{37}$ If, despite all measures taken, it is still not possible to determine the person's will and preferences, then one should not implement the principle of "best interest" but rather the principle of "best interpretation of will and preferences". ${ }^{38}$ The Committee therefore did not envisage taking into account anything but the will and preferences of the person, and it thereby makes a clear departure from the use of the functional capability test and the application of the principle of "best interest".

Unlike Art. 12 of the CRPD, which calls for the establishment of a new regime of supported decision-making that must be based on the respect for the rights, will, and preferences of the person being supported and leaves it up to States Parties to settle the matter in national law in accordance with the Convention principles, the General Comment goes one step further. Namely, the Committee stated very resolute conclusions on the content of Art. 12 and the obligations placed before States Parties that have not been explicitly included in the CRPD, so it is not surprising that they are the topic of numerous scientific and expert discussions. The main controversy surrounding this issue is whether to accept the wider interpretation of the Committee, which does not leave room for restriction of legal capacity based on mental capacity, or a narrower interpretation of Art. 12, which requires a departure from substitute decision-making to supported decision-making.

35 General Comment, op. cit., note 19, §14, 15 and 29 (i).

36 Ibid. $§ 26$.

37 Ibid. $\S 17$ and 28.

38 The Committee emphasized that "the "will and preferences" paradigm must replace the "best interests" paradigm to ensure that persons with disabilities enjoy the right to legal capacity on an equal basis with others." Ibid.§ 21. 


\section{ART. 12 OF THE CRPD AND GENERAL COMMENT NO 1: OPEN QUESTIONS}

\subsection{LEGAL CAPACITY VERSUS MENTAL CAPACITY}

The term "mental capacity" is not expressly mentioned in the Art. 12, but in the Committee's view any reference to decision-making capacity, while issuing a restriction of legal capacity, is discriminatory and contrary to the requirements of the CRPD. ${ }^{39}$ Among the authors who endorsed this interpretation of the Committee is Minkowitz, who considers that: "The Committee states that Article 12 calls for universal legal capacity, without discrimination based on disability. Removal of disqualifications based on disability moves us towards universal legal capacity, for two reasons. It means that we are separating "legal capacity" from "mental/functional/contractual capacity" and refusing any legal significance to the latter, so that legal capacity becomes an interface with the legal system as an actor and subject, free of any judgment about the person's decision-making skill." ${ }^{40}$

The principle of equality and prohibition of discrimination, invoked by the Committee and authors who support its interpretation, is one of the fundamental principles of the modern system of human rights and freedoms, which, due to its significance, is reflected in all fundamental human rights documents, including the CRPD. States Parties have undertaken to prohibit any discrimination based on disability and to guarantee to persons with disabilities equal and effective protection against discrimination on all grounds. ${ }^{41}$ However, despite the general acceptance of the principle of equality and the prohibition of discrimination, there is no consensus either in philosophy or the law and not even in the public opinion on what this actually means. ${ }^{42}$ The essence of anti-discrimination law is contained in the inadmissibility of treating a person or group of persons in a different, less acceptable way relative to another person or group of persons in similar circumstances. But the question remains how can this formal or legal equality be applied in the specific context of disability? ${ }^{43}$ Different treatment of persons may lead to discrimination, but it may also be justified if there is proper reason for such treatment. ${ }^{44}$ Starting from this approach, some authors consider it unacceptable that, in Committee's view, any reference to

39 Ibid. $\$ 15$.

40 Minkowitz, T., Submission to Committee on the Rights of Persons with Disabilities on the Draft General Comment on Article 12, 22 Jan. 2014, URL=https://www.ohchr.org/Documents/HRBodies/CRPD/GC/WNUSP. doc, Accessed 8 May 2019. Dhanda also considers that conditioning the legal capacity with the decision-making capacity privileges a certain group of persons and discriminates against another and discusses universal legal capacity as a universal human right. Dhanda contends the CRPD in Art. 12 recognizes the universal legal capacity for people with disabilities. Dhanda, A., Legal Capacity in the Disability Rights Convention: Stranglehold of the Past or Lodestar for the Future? Syracuse Journal of International Law and Commerce, Vol. 34, 2007, pp. 429-460, Dhanda, op. cit., note 13, pp. 177-188.

41 See Art. 5 of the CRPD. For more on equality and non-discrimination see Škorić, M., Utjecaj Konvencije o pravima osoba $s$ invaliditetom na kaznenopravni institut neubrojivosti, Zbornik Pravnog fakulteta Sveučilišta u Rijeci, Rijeka, Vol. 38, No. 3, 2017, pp. 1029-1032.

42 Compare Dworkin, R., Sovereign virtue, the theory and practice of equality, Harvard University Press, 2002.

43 For more on disability equality norms across European countries see Vanhala, L., The Diffusion of Disability Rights in Europe, Human Rights Quarterly, Vol. 37, 2015, pp. 839-844.

44 The ECHR has issued a number of judgments containing guidelines for demarcation between acceptable and unacceptable different treatment in the sense of Art. 14 of the European Convention for the Protection of Human Rights and Fundamental Freedoms. See Andrejeva v. Latvia, (2009), Abdulaziz, Cabales and Balkandali v. United Kingdom, (1985). 
psychological impairment in decision-making, which affects the person's right, is contrary to the CRPD. Dawson believes it is important to determine the basis on which people are treated differently. Without denying certain problems in accurate assessments of internal functioning and the state of the human mind, he points out that cognitive impairment can be considered relevant for certain decisions and that ignoring problems in a person's functioning can seriously endanger him or her and other persons' interests. In the opinion of this author, the Committee has given a radical interpretation of Art. 12 and he therefore cannot support its conclusion that the concept of mental capacity should be completely abandoned when deciding on legal capacity. ${ }^{45}$ Callaghan \& Ryan also criticize the interpretation of the Committee, which insists on abandoning the concept of decision-making as part of its legal capacity, while simultaneously failing to provide a coherent alternative account of the nature of the right to autonomy and its limits. Insisting on the standpoint that being autonomous means that every effort must be made to respect the expressed will, without bringing into question the capacity of the person to express it, opens up a series of practical and ethical questions to which the Committee has not provided answers. For example, what if the expressed will is based on a completely erroneous interpretation of relevant facts or on the lack of awareness of the seriousness of consequences that may arise from such a pronounced will. Callaghan \& Ryan emphasize, as the very core of the problem, that "while the autonomy theory in general is concerned with the concept of "agency," theories of universal capacity do not yet agree on the extent to which expressions of "will" and "preference" must also involve this characteristic and how it could be discerned." If we do not pay enough attention to the very expression of will and preferences, in practice this can be turned into mere "do what I say I want right now." ${ }^{\prime 6}$ Bartlett also thinks that the mental state may, in certain cases, be important for the proper response of the society, and that the fact that the psychological condition of a person has often been used in past in extremely inappropriate ways, does not necessarily mean that it always leads to discrimination. ${ }^{47}$ According to Bach \& Kerzer, the language of Art. 12 has adopted a wide range of different degrees of capacity, thus presenting a departure from the traditional dualistic model: mental capacity versus mental incapacity. In this way, the creators of the CRPD wanted to avoid problems arising from the system of guardianship, to ensure that a person never loses autonomy and also to enable people with disabilities to enjoy legal capacity on an equal basis as everyone else in all aspects of life. These authors have developed a model that differentiates between three possible decision-making statuses depending on the person's capacity to express his or her will and understand the nature and consequences of their decisions, namely: legally independent status, supported decision-making status and facilitated decision-making status. The latter would only be used as the last resort in cases where a person has a significant intellectual impairment and it is not possible to determine his or her will and preferences and there is no one close to the person who could give us the information about his or her wishes. Only in such cases may the principle of "best interest" be applied when making a decision. ${ }^{48}$

45 Dawson, J., A realistic approach to assessing mental health laws' compliance with the UNCRPD, International Journal of Law and Psychiatry, Vol. 40, 2015, pp. 70, 73.

46 Callaghan, S.; Ryan, R., Is there a future for involuntary treatment in Right-based Mental Health Law, Psychiatry, Psychology and Law, Vol. 21, No. 5, 2014, pp. 748, 755.

47 Bartlett, op. cit., note 26, p. 763.

48 Bach, M.; Kerzner, L., A new paradigm for protecting autonomy and the right to legal capacity, Advancing Substantive Equality for Persons with Disabilities through Law, Policy and Practice, Law commission of Ontario, 2010, pp. 6-9, 30, 82-94. URL=https://www. lco-cdo.org/wp-content/uploads/2010/11/disabilities-commissioned-paper-bach-kerzner.pdf. Accessed 8 May 2019. 
In the CRPD, very little attention is paid to the meaning of "will" and "preferences" or the way in which they are to be respected. On the other hand, the Committee has taken on quite a radical stance on these issues, which insists on respecting the expressed will without questioning the capacity of the person to express it. Literal and unwavering acceptance of the Committee's opinion that denies any possibility of referring to mental abilities when deciding on the legal capacity requires, in essence, abandoning the concept of mental capacity when making any decision that may affect the individual's right. Accepting such interpretation of Convention provisions would mean abandoning some of the fundamental principles of all modern legal systems. It would require, among other, substantial interventions in criminal justice systems of almost all Member States. Namely, in contemporary criminal legislation, the perpetrator's mental health has a direct effect on his or her culpability and persons with mental disabilities enjoy separate status in relation to other perpetrators of unlawful acts. ${ }^{49}$ Callaghan \& Ryan rightly point out that it is unclear, for example, whether the Committee believes that any denial of treatment should be taken as an expression of the person's will and whether such a decision should be always respected, regardless of the circumstances. If it had been the Committee's intention to prohibit assistance to a person who, for example, is delirious and expresses opposition to treatment, Callaghan \& Ryan conclude that this is a radical change that has significant implications which are not limited only to the respect for the right to autonomy. ${ }^{50}$ The Committee does not even allow for the possibility of providing support to depend on the person's mental capacity, but requires some other basis. However, by doing so the Committee did not state what this basis might be.

Without doubting the good intentions of Committee members, this interpretation, which some authors rightly deem radical, can ultimately produce a completely opposite effect and harm the rights of people with mental disabilities, as well as bring into question the possibility of achieving other CRPD requirements. ${ }^{51}$ Therefore, it is not surprising that there is a significant number of those who disagree with the interpretation provided by the Committee and point to the difference between, on the one hand, the mere exclusion of the person on the basis of his or her disability and, on the other hand, the denial of the person's right on the basis of his or her inability to perform a particular act. At the same time, it is not questionable that the assessment of mental capacity opens up a series of ethical and legal doubts regarding the issue of human autonomy and that it is an extremely complicated and complex process for which there is no gold standard. ${ }^{52}$ It is also undisputed that clearer criteria for determining mental capacity would certainly contribute to a better understanding of this term, but

49 That refers to both, the countries of the continental legal circle that consider the impact of mental illness on an individual's behavior primarily within the framework of guilt as an element in the dogmatic construction of a criminal offense, as well as common law countries, which take into consideration the question of the existence of mental illness, which may lead to the exclusion of guilt, within the procedural right to defense (insanity defense). For more see Škorić, op. cit., note 41, pp. 1027-1056.

Callaghan; Ryan, op. cit., note 46, p. 755. This problem is also emphasized by Szmukler, G., Submission to Committee on the Rights of Persons with Disabilities on the Draft General Comment on Article 12, 2014. URL= https://www.ohchr.org/EN/HRBodies/CRPD/ Pages/DGCArticles12And9.aspx. Accessed 8 May 2019.

51 Majstorović, I.; Šimović, I., Opseg lišenja poslovne sposobnosti kao pretpostavka zaštite prava i dostojanstva osoba s invaliditetom, Ljetopis socijalnog rada, Vol. 25, No. 1, 2018, pp. 72-73. Freeman, M. C. et al., Reversing hard won victories in the name of human rights: a critique of the General Comment on Article 12 of the UN Convention on the Rights of Persons with Disabilities, Lancet Psychiatry, Vol. 2, No. 9, 2015, p. 844, Szmukler, G., UN CRPD: Equal recognition before the law, Lancet Psychiatry, Vol. 2, No. 11, 2015, p. 29.

52 For more details, see Banner, N.; Szmukler, G., "Radical interpretation" and the Assessment of decision-making capacity, Journal of Applied Philosophy, Vol. 30, No. 4, 2013, pp. 379-382. 
it cannot be claimed that despite the absence of such criteria there is no basis for denying a particular person some right based on the inability to perform a particular act.

\subsection{REGIMES OF SUPPORTED DECISION-MAKING VERSUS REGIMES OF SUBSTITUTE DECISION-MAKING}

There are significant differences between the regimes of supported decision-making and substitute decision-making. The fundamental difference is that with substitute decision-making the consent of the person to whom the decision refers is not required and the final decision is made by a guardian who is guided by the principle of "best interest", while with supported decision-making the person to whom it refers makes the decision with the help of others. ${ }^{53}$ The common practice has allowed the guardian to make decisions on behalf of the person under guardianship based on the principle of "best interest" without taking into account the will and preferences of the person to which the decision applies. The CRPD, in turn, insists on respecting the rights, will, and preferences of the person being assisted. At the same time, the CRPD does not regulate the case when a person has a serious mental impairment and despite the provided support he or she cannot express their will and wishes and such persons undoubtedly exist. It is therefore important to answer the question whether, in accordance with the provisions of the CRPD, a third party, acting in accordance with the principle of "best interest", can make decisions on behalf of another person and, if so, under what conditions?

Bell et al. are of the opinion that substitute decision-making is in some cases inevitable and they point out that the Working Group of the Convention was aware of this fact. This conclusion is based on the text of Art. 12(4) due to the fact that it prescribes a series of safeguard measures to prevent misuse in supported decision-making. ${ }^{54}$ The explicit mention of substitute decision-making is considered unnecessary because "the requirements for the provision of support proportionate to the person's needs could encompass the whole range of support from highest to lowest." ${ }^{55}$ Donnelly also believes that substitute decision-making should be preserved for certain limited cases. ${ }^{56}$ Dowson points out that the text of Art. 12 should be interpreted in such a way that, before a decision is made on their legal capacity, the person must be provided with adequate support so that he or she can express their will and wishes on their own, and measures of reasonable adaptation in their environment should be undertaken which will improve their capacity to make a decision. However, if all these measures are not sufficient for a person to make a decision on their own, then it is imperative that other persons are empowered to make a decision on their behalf. In such exceptional situations, the person making the decision is still tied to the "best interpretation" of the concerned person's will and

53 For more details on the difference between supported decision-making and substituted decision-making see Caivano, op. cit., note 18 , pp. 4-5.

54 Art. 12(4) prescribes safeguards that must be present in a process of support-making decision to prevent abuse in accordance with international human rights law. It is important that measures relating to the exercise of legal capacity are "free of conflict of interest and undue influence, are proportional and tailored to the person's circumstances, apply for the shortest time possible and are subject to regular review by a competent, independent and impartial authority or judicial body". 
preferences. ${ }^{57}$ Minkowitz also states that substitute decision-making is not expressly prohibited in Art. 12 and that a part of the provision from paragraph 4, which refers to measures that relate to the exercise of legal capacity may, on its own, be interpreted in such a way as to include both supported and substitute decision-making. But Art. 12(4) must not be interpreted in a way that presumes the existence of substitute decision-making, but rather, on the contrary, must be interpreted in such a way that the rights, will, and preferences of the person must always be taken into account. ${ }^{58}$ Callaghan \& Ryan point out that if a person with serious impairment is given $100 \%$ support to make a decision, one cannot deny that it is quite certain that the decision was actually made by the person providing the support. In such a case, it is legal fiction that this is about supported decision-making. In reality, this is substitute decision-making, but there is no supervision that is characteristic of this form of decision-making. In the opinion of these authors, insisting solely on supported decision-making will result in the fact that required safeguard means in certain cases will exceed those that are usually characteristic of this form of decision-making. ${ }^{59}$ This places an enormous burden on the system of supported decision-making and creates a vague legal nature of the decisions that are being made. These authors have pointed out an extremely important issue to be addressed with regards to the establishment of protective mechanisms within the supported decision-making system that should prevent misuse and ensure that the final decision is the result of the real will and preferences of the person to whom it refers. ${ }^{60}$ Namely, the introduction of supported decision-making system can have unforeseeable adverse consequences for people with mental disabilities if the so far constructed protective mechanisms, which are characteristic of the substitute decision-making model, are not implemented, further improved and developed. It would be very unfortunate if countries were to meet the CRPD requirements by simply replacing the names so that what they used to call substitute decision-making has now become supported decision-making without providing adequate protection mechanisms. The position of the person with mental disabilities would in that case be worse due to the loss of control mechanisms associated with substitute decision-making.

It is crucial to note that Art. 12 obliges the States to build a supported decision-making system that must be proportionate to the needs of the individual. It should cover a whole range of different forms of support, whereby the person providing support should build a personal relationship with the person he or she is helping and take the appropriate steps to make full use of their potential. Dinerstein defines supported decision-making as: “... a series of relationships, practices, arrangements and agreements, of more or less formality and intensity, designed to assist an individual with a disability to make and communicate to others decisions about the individual's life... A purer form of supported decision-making would rely on peer support (for example, ex-users of psychiatric services for people with psycho-social disabilities), community support networks and personal assistance, so-called natural supports

57 Dawson, op. cit., note 45, p. 74.

58 Minkowitz, T., Abolishing Mental Health Laws to Comply with the Convention on the Rights of Persons with Disabilities in: McSherry, B.; Weller, P. (eds.), Rethinking rights-based mental health laws, Hart Publishing Ltd, Oxford and Portland, Oregon, 2010, pp. 156-157.

60 Callaghan; Ryan, op. cit., note 46, pp. 756-760. Compare Gooding, P., Navigating the "Flashing Amber Lights" of the Right to Legal Capacity in the United Nations Convention on the Rights of Persons with Disabilities: Responding to Major Concerns, Human Rights Law Review, Vol. 15, No. 1, 2015, pp. 55-57. 
(family, friends), or representatives (pursuant to a representation agreement) to speak with, rather than for, the individual with a disability". ${ }^{61}$

Minkowitz also lists different types of support that can be provided to a person (peer support, community support networks, personal assistance, etc.), as well as support programs developed in individual countries. According to her opinion the diverse spectrum of protective mechanisms envisaged in Art. 12(4) will be applied differently depending on the type of aid, as well as the legal work for which the aid is envisaged. ${ }^{62}$

Schulz points out that one of the major challenges during the negotiations has been the precise clarification that the level of support and help within the supported decision-making system will be smaller or higher and will vary between $0 \%$ and $100 \% .{ }^{63}$ However, it is important to note that the determination and respect for the true will and preferences of the person being supported are at the very core of supported decision-making and exactly this point presents a difference embodying the new paradigm which has been promoted by the CRPD. ${ }^{64}$ In other words, we are dealing with supported decision-making also if the degree of support amounts to $100 \%$, provided that the final decision is based on the (previously) expressed will and preferences of the person. In this way, the regime of supported decision-making can also be applied in extreme situations, e.g. when a person is lying in a coma, because even then previously expressed wishes, abiding values, and experience with similar situations can be discovered, relying thereby on the support of family, friends, neighbors and all other people who can provide help. ${ }^{65}$ A decision made by a third party in such a case would not be considered substitute but rather supported until it reflects the previously stated will of the person to whom it relates. Schulz further points out that the need for the highest level of support will be extremely rare if a good support system has been provided. ${ }^{6}$ Indeed, an adequate support system on which the CRPD insists can greatly facilitate and ultimately empower the person to make decisions in the future.

Nevertheless, it cannot be argued that it will always be possible to determine the will and preferences of the person to whom the decision refers. Therefore, it is not entirely possible to exclude the possibility that in some cases a third party should make the decision based on the principle of "best interest" ${ }^{67}$ But, with a well-designed and developed support system, such situations should in practice be exceptionally rare.

61 Dinerstein, R., Implementing Legal Capacity Under Article 12 of the UN Convention on the Rights of Persons with Disabilities: The Difficult Road From Guardianship to Supported Decision-Making, Human rights brief, Vol. 19, No. 2, 2012, p. 10.

62 See Minkowitz, op. cit., note 11, p. 409, Minkowitz, op. cit., note 58, p. 157.

63 Schulze, op. cit., note 22, p. 60.

64 Compare Minkowitz, op. cit., note 58, pp. 157-159.

65 One of the most frequently asked question about Art. 12 was the manner in which its demands should be met in the event that a person cannot express his or her will and wishes even with provided support (e.g. person in a coma). See Gooding, supra note 59, at 53-55, Del Villar, K., Should supported decision-making replace substituted decision-making? The Convention on the Rights of Persons with Disabilities and Coercive Treatment under Queensland's Mental Health Act 2000, Laws, Vol. 4, No. 2, 2015, pp. $192-194$.

66 Schulze, op. cit., note 22, p. 60.

67 Perhaps, in such cases, consideration might be given to the use of some other term instead of substituted decision-making, which would be a clear departure from the previous practice. Thus Bach and Kerzner use the term 'facilitated decision-making status' for cases when a person has significant intellectual impairment and it is not possible to determine his or her will and preferences and neither is there a person who could help in this endeavor. Bach; Kerzner, op. cit., note 48, pp. 91-94. 


\section{CONCLUSION}

Despite the various interpretations of the content of Art. 12, it is undisputed that the legal capacity of all persons with disabilities is presumed and that it includes both the capacity for rights and the capacity to act. It is also unquestionable that those persons who need support to realize their legal capacity must be provided with it and that the rights, will, and preferences of the person being supported must be respected. Consequently, the entry into force of the CRPD no longer raises the question does a person have the mental capacity to exercise their legal capacity but rather what types of support are required for the person to exercise his or her legal capacity. ${ }^{68}$ It is crucial to note that requirements of Art. 12 of the CRPD cannot be met without a clear departure from the common practice, which has too lightly reached for the institute of guardianship.

At the same time, it cannot be denied that there are persons who, despite the best will and the greatest support, cannot make a decision. The CRPD does not provide an explicit answer what should be done in such cases and it is perfectly legitimate to raise the question why the CRPD is silent on this extremely important issue. Maybe we could answer this question more easily if we rearranged it and asked ourselves the following: If the CRPD provided that under some exceptional circumstances the legal capacity of persons with disabilities can be denied, could any improvement of their real position be expected? Previous experiences clearly show that this is not the case! By prescribing such an exception, this Convention would be just one more set of human rights documents that would not substantially improve the position of people with disabilities. Namely, all previous international documents relating to persons with mental disabilities considered that control over these persons was, in certain cases, justified, while the allowed limit of control was a matter of discussion. The CRPD starts from a completely opposite position - stressing that the control of their life belongs exclusively to them and placing into the foreground their decision-making capacity and fundamental human rights. When recalling the treatment of people with mental disabilities throughout history, as well as a number of examples of abuse of their rights, it is quite understandable that respect for their will is one of the fundamental goals of the CRPD, which must be supported without reservation. Therefore, the silence of the CRPD on what to do when we are unable to determine the will of a person, as well as other important issues, should not be considered its shortcoming. On the contrary, this provides States Parties with the freedom to independently develop support models in accordance with the objectives and principles set forth in the CRPD and to take measures that will enable persons with mental disabilities to become subjects with the right to their own choices and exercise autonomous decision-making, instead of them being objects of a third party's decisions.

The problem of not recognizing the capacity of persons with mental disabilities is deeply rooted in our society and, above all, we have to ask ourselves, both as lawyers, doctors, members of the family of persons with mental disabilities, and as citizens, if we are truly ready to hear and respect the will of the people with mental disabilities? The paradigm shift on which the CRPD insists assumes the true desire to create an adequate social environment in which everyone, regardless of the existence or absence of disabilities, will be able to achieve full and 
free development and realize their full potential. Due to the ratification of the CRPD and the adoption of new legislation, the status of these persons will not improve if they are not backed up by appropriate transformations of political processes. ${ }^{69}$ Such transformation should create an environment where the rights of the person with disabilities are seen as "the primary departure point and not as an annoying distraction."70 This should be a solid foundation on which a new system should be built, but for which there is still no established practice and scientific research is lacking. Therefore, its establishment necessarily presupposes a certain dose of courage and risk taking. ${ }^{71}$ But, we should not be afraid; we should simply try to understand.

\section{REFERENCES}

1. Banner, N.; Szmukler, G., "Radical interpretation" and the Assessment of decision-making capacity, Journal of Applied Philosophy, Vol. 30, No. 4, 2013, pp. 379-394.

2. Bartlett, P., 'The United Nations Convention on the Rights of Persons with Disabilities and Mental Health Law', Modern Law Review, Vol. 75, No. 5, 2012, pp. 752-778.

3. Bell, S.; McGregor, J.; Wilson, M., The Convention on the Rights of Disabled Persons: A Remaining Dilemma for New Zealand?, New Zealand Journal of Public and International Law, Vol. 13, 2015, pp. 277-296.

4. Caivano, N., Conceptualizing Capacity: Interpreting Canada's Qualified Ratification of Article 12 of the UN Disability Rights Convention, Western Journal of Legal Studies, Vol. 4, No. 1, 2014, pp. 1-24.

5. Callaghan, S. M.; Ryan C., An evolving revolution: Evaluating Australia's compliance with the Convention on the Rights of Persons with Disabilities in Mental Health Law, UNSW Law Journal, Vol. 39, No. 2, 2016, pp. 596-624.

6. Callaghan, S. M.; Ryan C., Is there a future for involuntary treatment in Right-based Mental Health Law, Psychiatry, Psychology and Law, Vol. 21, No. 5, 2014, pp. 747-766.

7. Dawson, J., A realistic approach to assessing mental health laws' compliance with the UNCRPD, International Journal of Law and Psychiatry, Vol. 40, 2015, pp. 70-79.

8. Degener, T.; Begg, A., From Invisible Citizens to Agents of Charge: A Short History of the Struggle for the Recognition of the Rights of Persons with Disabilities at the United Nations, in: Della Fina et al. (eds.), The United Nations Convention on the Rights of Persons with Disabilities, A Commentary, Springer, 2017, pp. 1-40.

9. Del Villar, K., Should supported decision-making replace substituted decision-making? The Convention on the Rights of Persons with Disabilities and Coercive Treatment under Queensland's Mental Health Act 2000, Laws, Vol. 4, No. 2, 2015, pp. 173-200.

10. Dhanda, A., Universal legal capacity as a universal human right, in: Dudley, M., Silove, D., Gale, F., Mental Health and Human Rights: Vision, Praxis, and Courage, Oxford: Oxford University Press, 2012, pp. 177-188.

69 Fiala, J., Konvencija o pravima osoba s invaliditetom i reforma skrbništva u Središnjoj i Istočnoj Europi, in: Poslovna sposobnost i skrbništvo - raskorak između Konvencije o pravima osoba s invaliditetom i prakse, Pravobraniteljica za osobe s invaliditetom, Zagreb, 2012, p. 92.

70 Quinn, G., Resisting the "Temptation of Elegance": Can the Convention on the Rights of Persons with Disabilities Socialise States to Right Behaviour? in: Arnardóttir, A; Quinn, G. (eds.), The UN Convention on the Rights of Persons with Disabilities: European and Scandinavian perspectives, Leiden, Martinus Nijhoff, 2009, p. 256. 
11. Dhanda, A., Legal Capacity in the Disability Rights Convention: Stranglehold of the Past or Lodestar for the Future?, Syracuse Journal of International Law and Commerce, Vol. 34, 2007, pp. 429-462.

12. Dinerstein, Robert D., Implementing Legal Capacity Under Article 12 of the UN Convention on the Rights of Persons with Disabilities: The Difficult Road From Guardianship to Supported Decision-Making, Human Rights Brief, Vol. 19, No. 2, 2012, pp. 8-12.

13. Donnelly, M., Best interests in the Mental Capacity Act: Time to say goodbay, Medical Law Review, Vol. 24, No. 3, pp. 318-332.

14. Fiala, J., Konvencija o pravima osoba s invaliditetom i reforma skrbništva u Središnjoj i Istočnoj Europi, in: Poslovna sposobnost i skrbništvo - raskorak između Konvencije o pravima osoba s invaliditetom i prakse, Pravobraniteljica za osobe s invaliditetom, Zagreb, 2012, pp. 90-96.

15. Flynn, E.; Arstein-Kerslake, A., The Support Model of Legal Capacity: Fact, Fiction, or Fantasy?, Berkley Journal of International Law, Vol. 23, No. 1, 2014, pp. 124-143.

16. Freeman, M.C. et al., Reversing hard won victories in the name of human rights: a critique of the General Comment on Article 12 of the UN Convention on the Rights of Persons with Disabilities, The Lancet Psychiatry, Vol. 2, No. 9, September 2015, pp. 844-850.

17. Gooding, P., Navigating the "Flashing Amber Lights' of the Right to Legal Capacity in the United Nations Convention on the Rights of Persons with Disabilities: Responding to Major Concerns, Human Rights Law Review, Vol. 15, No. 1, 2015, pp. 45-71.

18. Korać Graovac, A.; Čulo, A., Konvencija o pravima osoba s invaliditetom - novi pristup shvaćanju prava osoba s duševnim smetnjama, Zbornik Pravnog fakulteta u Zagrebu, Zagreb, Vol. 61, No. 1, 2011, pp. 65-109.

19. Lewis, O., The Expressive, Educational and Proactive Roles of Human Rights: An Analysis of the United Nations Convention on the Rights of Persons with Disabilities, in: McSherry, B.; Weller, P., Rethinking Rights-Based Mental Health Laws, Hart Publishing Ltd, Oxford and Portland, Oregon, 2010, pp. 97-128.

20. Majstorović, I.; Šimović, I., Opseg lišenja poslovne sposobnosti kao pretpostavka zaštite prava i dostojanstva osoba s invaliditetom, Ljetopis socijalnog rada, Vol. 25, No. 1, 2018, pp. 65-84.

21. McSherry, B., Decision-Making, Legal Capacity and Neuroscience: Implications for Mental Health Laws, Laws, 2015, 4, pp. 125-138.

22. Minkowitz, T., The United Nations Convention on the Rights of Persons with Disabilities and the right to be free from non-consensual psychiatric interventions, Syracuse Journal of International Law and Commerce, Vol. 34, No. 2, 2007, pp. 405-428.

23. Minkowitz, T., Abolishing Mental Health Laws to Comply with the Convention on the Rights of Persons with Disabilities, in: McSherry, B., Weller, P., Rethinking Rights-Based Mental Health Laws, Hart Publishing Ltd, Oxford and Portland, Oregon, 2010, pp. 151-177.

24. Quinn, G., Rethinking Personhood: New Directions in Legal Capacity Law \& Policy or How to Put the "Shift" back into "Paradigm Shift", in: Janjic, B.; Beker, K.; Marković, M. (eds.), Legal capacity and community living: protection of the rights of persons with disabilities, Mental Disability Rights Initiative MDRI-S, Belgrade, 2014, pp. 17-39.

25. Quinn, G., 'Resisting the "Temptation of Elegance": Can the Convention on the Rights of Persons with Disabilities Socialise States to Right Behaviour?' in: Arnardóttir, O., M., Quinn, G. (eds.), The UN Convention on the Rights of Persons with Disabilities: European and Scandinavian Perspectives, Leiden, Martinus Nijhoff, 2009, pp. 215-256.

26. Schulze, M., Understanding The UN Convention on the Rights of Persons with Disabilities, A Handbook on the Human Rights of Persons with Disabilities, Handicap International, 2009. 
27. Stein, M., A.; Lord, J. E., Monitoring the Convention on the Rights of Persons with Disabilities: Innovations, Lost Opportunities, and Future Potential, Human Rights Quarterly, Vol. 12, 2010, pp. 689-728.

28. Szmukler, G., "Capacity", "best interests", "will and preferences" and the UN Convention on the Rights of Persons with Disabilities, World Psychiatry, Vol. 18, No. 1, 2019, pp. 34-41.

29. Szmukler, G., UN CRPD: Equal recognition before the law, Lancet Psychiatry, Vol. 2, No. 11, 2015, p. 29.

30. Škorić, M., Utjecaj Konvencije o pravima osoba s invaliditetom na kaznenopravni institut neubrojivosti, Zbornik Pravnog fakulteta Sveučilišta u Rijeci, Vol. 38, No. 3, 2017, pp. 1027-1056.

31. Štrkalj Ivezić, S., Procjena kapaciteta za odlučivanje kao ključan faktor u donošenju odluke za lišavanje poslovne sposobnosti, in: Poslovna sposobnost i skrbništvo - raskorak između Konvencije o pravima osoba s invaliditetom i prakse, Pravobraniteljica za osobe s invaliditetom, Zagreb, 2012, pp. 66-75.

32. Vanhala, V., The Diffusion of Disability Rights in Europe, Human Rights Quarterly, Vol. 37, 2015, pp. 831-853.

\section{LIST OF REGULATIONS, ACT AND COURT DECISIONS}

1. United Nations Convention on the Rights of Persons with Disabilities, The Official Gazette, International Treaties, 67/2007, 5/2008.

2. United Nations Committee on the Rights of Persons with Disabilities, General Comment no 1: Article 12: Equal recognition before the law, CRPD/C/GC/1, 19 May 2014.

\section{WEBSITE REFERENCES}

1. Bach, M., Kerzner, L., A new paradigm for protecting autonomy and the right to legal capacity, Advancing Substantive Equality for Persons with Disabilities through Law, Law Commission of Ontario, 2010. URL=https://www.lco-cdo.org/wp-content/uploads/2010/11/disabilities-commissioned-paper-bach-kerzner.pdf.

2. Minkowitz, T., Submission to Committee on the Rights of Persons with Disabilities on the Draft General Comment on Article 12, 2014. URL=https://www.ohchr.org/Documents/HR Bodies/ CRPD/GC/ WNUSP. doc.

3. Nilsson, A., Who gets to decide? Right to legal capacity for persons with intellectual and psychosocial disabilities, Council of Europe: Commissioner for Human Rights 2012. URL= https://rm.coe. int/16806da5c0.

4. Szmukler, G., Submission to Committee on the Rights of Persons with Disabilities on the Draft General Comment on Article 12, 2014. URL=https://www.ohchr.org/EN/HRBodies/ CRPD/Pages/ DGCArticles12And9.aspx.

5. Pravobraniteljica za osobe s invaliditetom, Izvješće o radu Pravobraniteljice za osobe s invaliditetom za 2015. URL=http://posi.hr/wp-content/uploads/2018/01/IZVJESCE-O-RADU-UREDA-PRAVOBRANITELJICE-ZA-OSOBE-S-INVALIDITETOM-ZA-2015.pdf.

6. European Union Agency for Fundamental Rights, Legal capacity of persons with intellectual disabilities and persons with mental health problems, Publications Office of the European Union, Luxembourg, 2013. URL=https://fra.europa.eu/sites/default/files/legal-capacity-intellectual-disabilities-mental-health-problems.pdf. 
Marissabell Škorić*

\section{STOLJEĆE - POČETAK NOVE \\ ERE U ZAŠTITI LJUDSKIH PRAVA OSOBA S DUŠEVNIM SMETNJAMA}

\section{Sažetak}

U radu se analizira odredba čl. 12. Konvencije o pravima osoba s invaliditetom te njezin utjecaj na položaj osoba s duševnim smetnjama. Nova koncepcija poslovne sposobnosti sadržana u čl. 12. trebala bi osigurati da temeljna ljudska prava osoba s duševnim smetnjama više ne budu mrtvo slovo na papiru. No, nakon što je Konvencija stupila na snagu, implementacija ove odredbe pokazala se problematičnom za države stranke. O razmjerima problema najbolje govori izjava Diane Kingston, bivše potpredsjednice Odbora za prava osoba s invaliditetom, iz listopada 2015., kako dotad nijedna zemlja nije u potpunosti udovoljila zahtjevima sadržanima u čl. 12. S obzirom na to da je Konvencija dokument koji propisuje temeljna ljudska prava, izjava kako nijedno nacionalno zakonodavstvo nije usklađeno s njegovom ključnom odredbom zbunjujuća je i zabrinjavajuća te zahtijeva da se odredbi čl. 12. posveti posebna pozornost.

Ključne riječi: $\quad$ Konvencija o pravima osoba s invaliditetom, osobe s duševnim smetnjama, ljudska prava, poslovna sposobnost, sposobnost odlučivanja, potpomognuto odlučivanje

\section{(c) (i) (5)}

This work is licensed under a Creative Commons

Attribution-NonCommercial 4.0 International License.

* $\quad$ Dr. sc. Marissabell Škorić, izvanredna profesorica, Pravni fakultet Sveučilišta u Rijeci, Hahlić 6, 51000 Rijeka, Republika Hrvatska. Adresa e-pošte: skoric@pravri.hr. ORCID: https://orcid.org/0000-0003-0627-3651. 